\title{
O professor e o ensino a distância
}

\author{
Prof. Dr. Gilberto Perez Cardoso*
}

Em recente pesquisa de opinião, levada a cabo na Universi dadedeSão Paul ${ }^{(1)}$, equeenvolveu 280 alunos dos cursos degraduação nas áreas de Comunicação, Administração, Economia, Psicologia, Engenharia, Direito, Medicina eEducação, parcelaimportante desses alunos (em torno de 18\%) revel ou acreditar que o professor estaria com os dias contados. Para esses estudantes, os mestres logo perderiam espaço para as máquinas- em especial para o computador.

Essesmesmosal unos, segundo a pesquisa, achamque seu aprendizado será permanenteao longo de toda a sua vida (98\%); quemuitas aulas, em breve, serão ministradas a distância (62\%); quepoderão, em futuro próximo, montar seus próprios currículos, escolhendo as matérias que mais Ihesagradarem duranteos cursos (55\%), equeferramentas tecnológicas de ensino, tais como TV, vídeo e vídeo-conferência, serão fundamentais (55\%).

É curioso, contudo, observar da pesquisa, queo mesmo grupo acha queo professor continuaráa existir (só 18\% acham que não), que o diploma continuará a ser importante (só $17 \%$ acham que não), e que os livros em papel continuarão tendo relevantefunção (só 7\%acham quenão).

Emmuitosaspectos, essavisão dosestudantes daUSP parececoincidir com a daqueles que, ultimamente, têm-se entusiasmado com a chamada "educação a distância", chegando, por vezes, à euforia deparecer dispensar a atuação do professor, quesetornariafigurasupérflua no processo deensino-aprendizagem.

Na pesquisa em questão foram entrevistados 40 estudantes de cada curso, eal gumas informações são ainda mais interessantes. A mai oria acha que, do quelhefoi informado naescola, efetivamenteaprendeu entre $50 \%$ e $70 \%$, no máximo. E que a mel hor forma de aprendizado foi, a saber: aula expositiva (31\%); estudo sozinho (30\%); trabaIhos em grupo ou em seminários (20\%), erealizando pesquisas práticas (14\%). A maioria acredita que os alunos,

* Professor Titular de Medicina Interna, Coordenador Geral da PósGraduação em M edicina da Universidade Federal Fluminense. no futuro, assim como também os professores, vão estar mais envolvidos com afaculdadeequeas aulas serão mais dinâmicas, mais práticas eparticipativas (34\%).

O interessanteécompararmos al gumas respostas dadas pel o conjunto dos al unos com aquel as fornecidas peIos al unos de Medicina. Osalunos de M edicina, em relação ao conjunto, acreditam também quea aprendizagem será contínua por toda a vida ( $100 \% \times 98 \%)$; quemuitas aulas serão dadas via Internet $(68 \% \times 62 \%)$, equeferramentas tecnológicas serão importantes no ensino (68\%× $55 \%)$. Massão em menor número os que seacham capazes demontar sozinhos o próprio curso ( $38 \% \times 55 \%$ ), eosque concordam com a hipótese do desaparecimento do professor $(3 \% \times 18 \%)$ ecom a possibilidadedo desaparecimento dolivro em papel $(5 \% \times 7 \%)$.

O grupo considera, ainda, como ponto positivo no "ensino a distância", a flexibilidadeea comodidade do horário (38\%) eo conforto denão precisar sedeslocar (29\%). É compreensível até, especialmentenum grandecentro (com as dificuldades dedesl ocamento, os riscos deassaltos, etc.), queo ensino a distância seja festejado pel o seu aspecto de ser cômodo. Contudo, éinteressanteobservar queo mesmo grupo, quando convidado a destacar os aspectosnegativos detal modalidade deensino, tenha apontado "falta dapresença, experiência, contato físico eintermediação do professor", especialmentepara esclarecer dúvidasimediatas (45\%). Além disso, 23\% acham que "o ensino virtual fica muito impessoal, superficial eperdeo contato humano, queéfundamental". Demaneira muito significativa, osalunos deM edicina achamainda quea "educação a distância" poderia ser útil em matérias que não necessitassem de contato com o paciente (Bioquímica, Estatística, Epidemiologia, etc.) e naquelas basicamente teóricas Microbiologia, Fisiologia, Patologia e Histologia, entre outras. Dos al unos de Medicina, 71\%acham que "a educação a distância não funcionaria em Clínica, Propedêutica, A natomia eCirurgia".

Por fim, quando indagados sobre se um curso a distânciapoderiadar certosemnenhumcontatohumanopre- 
sencial, $89 \%$ dos alunos do grupo de 280 responderam taxativamente que não.

A pesquisa fala por si só. A chamada "educação a distância", a nosso ver, é mais um método (às vezes muito eficienteecômodo) quepodeauxiliar o professor no processo deensino-aprendizagem. Seriatolice, entretanto, festejá-lo como solução para todos os problemas do ensino, como uma panacéia para sol ucionar a nossa ignorância. Asopiniões mostram claramenteas limitações dessa modalidade, assim como são limitadasas longas aulas expositivaseaborrecidas as projeções seguidas dediapositivos com a luz apagada, enquanto a platéia seentrega gostosamenteao sono profundo.

N uma área como a médica, em queoaprender seconfunde, essencial menteeem muitas ocasiões, com ofazer ,é preciso não nos deixarmos entusiasmar açodadamentepor métodos de ensino que nos afastem do paciente. Aliás, anteriormentejá tivemos a oportunidade deapontar, do ponto de vista do rendimento educacional, a limitação de cursos teóricos, congressos esimpósios. Eles podeminformar a novidade, mas não formam e não treinam, porque isso só seobtém pelaprática.

Com relação aos métodos interativos, especialmente os computadorizados, começam a aparecer importantes críticos, e com conhecimento de causa. Recentemente, numa obra intitulada " $\mathrm{H}$ igh-tech heretic, reflections of a computer contrarian" (2), Clifford Stoll, cujo nomedispensa comentários para os aficionados pela Informática, despeja uma ducha deágua fria sobre os defensores das maravilhas da Internet na escola. Segundo ele, "não se podem substituir bons professores por bons computadores ou bons "websites"; não se podem sequer substituir maus professores por um bom "software" ". Ainda segundo a abalizada opinião deStoll, "absolutamentenada substitui a boa evel ha relação professor/ aluno". Naobra em questão, Stoll critica a pedagogia norte-americanapelo endeusamento da Informática eindaga sobre o que seria mais eficiente: despejar uma enxurrada de informações sobre os alunos ou desenvolver neles a sensibilidade necessária para poder interpretá-las?

Particularmente, estamos em total concordância com Stoll, aceitando a Informática como uma grandeferramenta ao nosso dispor, e festejando os métodos interativos de educação não-presencial como bons auxiliares no ensino médico emesmo na abordagem do paciente-masjamais cometendo a insensatez deinverter os papéis esubordinar o homemà máquina eas relações professor/ al uno ou mé dico/ pacienteao "software" engenhoso ou à tel econferência espetacular.

Parecesensato colocarmos as coisas em seus devidos lugares elembrar que, na história da civilização, muitos feitos tecnológicos jásurgiram... etambém seforam.

O ser humano, porém, ficou.

(1) http:/ / www.aprendiz.org.br/ .

(2) http:/ / www.anchorbooks.com 